\title{
The potential risk of heavy metals on human health due to the daily consumption of vegetables
}

\author{
Amir Hossein Baghaie ${ }^{1^{* \mathbb{D}}}$, Mohammad Fereydoni ${ }^{1}$ \\ ${ }^{1}$ Department of Soil Science, Arak Branch, Islamic Azad University, Arak, Iran
}

\begin{abstract}
Background: Vegetables are one of the most important components of daily food. Thus, this research was done to evaluate the potential risk of heavy metals on human health due to the consumption of vegetables distributed in the fruits and vegetables central market of Arak, Iran.

Methods: In this study, a total 45 samples from edible parts of parsley, mint, chard, fenugreek, cress, basil, coriander, lettuce, and cabbage distributed in the fruits and vegetables central market of Arak were randomly collected and the concentration of heavy metals including lead $(\mathrm{Pb})$, cadmium $(\mathrm{Cd})$, and arsenic (As) in these crop plants was measured using atomic absorption spectrophotometer (AAS). The non-carcinogenic risk of heavy metals intake through the consumption of the studied vegetables was evaluated for male and female using the Environmental Protection Agency (EPA) method.

Results: The highest and lowest $\mathrm{Pb}$ daily intake and $\mathrm{Pb}$ risk index was related to the consumption of cabbage and basil, respectively. And the highest daily intake of $\mathrm{Cd}$ and As was related to lettuce consumption, while the lowest daily intake of these metals was related to the consumption of coriander. Among the studied heavy metals, As had the highest hazard quotient (HQ) for non-carcinogenic diseases. The highest HQ belonged to As through lettuce consumption and the lowest one belonged to As through coriander consumption (58 g/day). The HQ for female was higher than that for male. Conclusion: According to the results, the total hazard quotient (THQ) of non-carcinogenic diseases from the total studied vegetables was above the standard level. On the other hand, the HQ for female was higher than that for male.

Keywords: Human, Vegetables, Risk Factor, Arsenic, Lead

Citation: Baghaie AH, Fereydoni M. The potential risk of heavy metals on human health due to the daily consumption of vegetables. Environmental Health Engineering and Management Journal 2019; 6(1): 11-16. doi: 10.15171/EHEM.2019.02.
\end{abstract}

\section{Article History:}

Received: 10 October 2018

Accepted: 10 January 2019

ePublished: 2 February 2019

\section{Introduction}

Vegetables are important sources of nutrient elements for human health such as potassium, fiber, and vitamins. Evidence from various studies suggests that daily consumption of vegetables can prevent the development of cardiovascular diseases and some cancers, especially gastrointestinal cancers (1-3). However, the consumption of vegetables grown in heavy metal-contaminated soils can lead to harmful metabolic and physiological effects on human body $(4,5)$. High application of organic and inorganic fertilizers in the fields can lead to the accumulation of nitrates and heavy metals in crop plants, and consequently, the consumption of these products can threaten human health (6-8).

It is well known that lead $(\mathrm{Pb})$, arsenic (As), and cadmium (Cd) are very toxic heavy metals for human health (911), that directly or indirectly enter human body (Figure 1). Soil and water pollution by heavy metals is one of the human societies problems, that reduce yield and quality of agricultural products and threaten human health $(12,13) . \mathrm{Pb}$ is not a necessary element for human health, and its high intake has different harmful effects such as enzymatic and nervous problems, skeletal damages, and immune system damage (14). Exposure to As causes various problems such as skin damages, peripheral neuropathy, and vascular diseases (15). Moreover, chronic exposure to $\mathrm{Cd}$ causes different problems and diseases such as lung cancer, prostate problems, kidney disease, and osteoporosis. Even the intake of necessary elements with significant biological effects can threaten human health. Overall, after penetration of metals into cells, they are affected by oxidation and reduction (redox) potential, which can disturb the intracellular reactions in living cells (11).

Heavy metals enter human body through various pathways (Figure 1) such as inhalation, dust and air pollution, and 


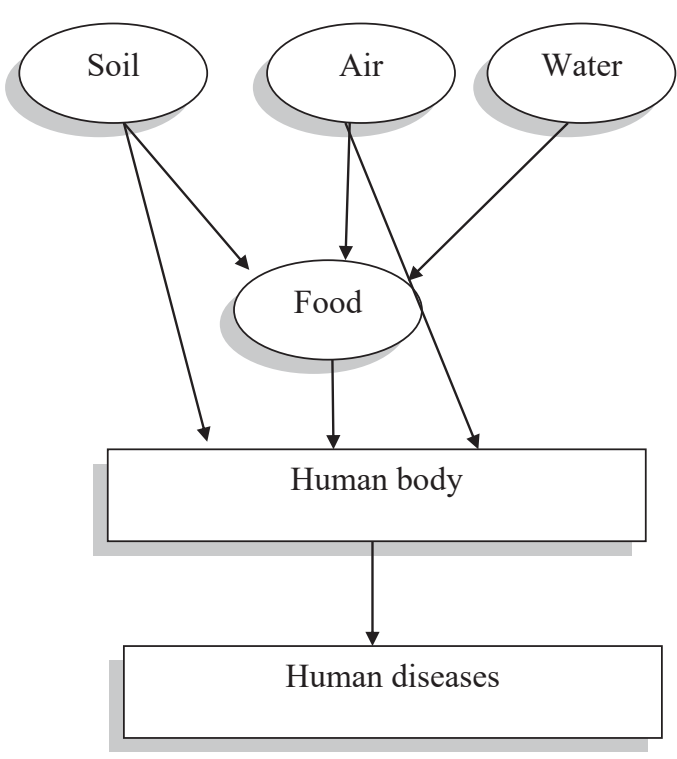

Figure 1. Different pathways of heavy metals entrance into human body.

the consumption of vegetables grown in the contaminated soils (16). Accordingly, assessment of the heavy metals health risk seems necessary (17-19), although reducing heavy metals concentration is a useful method for protection of human health (20).

Qishlaqi et al studied the impact of wastewater irrigation on soils and crops in Shiraz suburban area and reported that the Cd hazard quotient (HQ), due to the consumption of agricultural crops irrigated with untreated wastewater, was higher than the standard level (21). Nazemi el al investigated the heavy metals concentration in the vegetables cultivated in the suburbs of Shahroud county and reported that the risk index of the studied heavy metals enter human body by the consumption of cultural vegetables was higher than one, that was due to the land irrigation with urban and industrial wastewater contaminated with heavy metals (5). As heavy metals can play a role in the development of carcinogenic and noncarcinogenic diseases (22-24), assessment of risk index for these diseases due to the consumption of contaminated vegetables has an important role in promoting human health.

Kheirabadi et al investigated the carcinogenic risk of heavy metals in wheat and potato in Hamadan province and reported that the HQ of non-carcinogenic diseases in the exposure to each element was below the standard level $(\mathrm{HQ}=1)(25)$.

Regarding the importance of vegetables to human health, it is necessary to evaluate the heavy metals concentration in the edible parts of vegetables in regional studies (22). Therefore, this research was done to estimate the health risk of heavy metals intake through the consumption of different vegetables distributed in the fruits and vegetables central market of Arak in 2017.
Materials and Methods

In order to investigate the health status of the vegetables distributed in the fruits and vegetables central market of Arak, nine types of vegetables including parsley, mint, chard, fenugreek, cress, basil, coriander, lettuce, and cabbage, were randomly selected. The weeds were separated from the vegetables and the edible parts of the vegetables were washed with water, and then, dried in an oven $\left(60\right.$ to $\left.65^{\circ} \mathrm{C}\right)$ and powdered with a mixer. $\mathrm{Pb}, \mathrm{As}$, and $\mathrm{Cd}$ were extracted from the vegetables using three acid (nitric acid, perchloric acid, and sulfuric acid) digestion method with the ratio 1:1:5 (16). The concentration of heavy metals was determined using atomic absorption spectrophotometer (AAS, Model 3030).

The risk index for $\mathrm{Pb}$ and $\mathrm{Cd}$ in vegetables distributed in the fruits and vegetables central market of Arak was calculated using the formula proposed by the U.S. Environmental Protection Agency (EPA) (25-27).

$\mathrm{HQ}=(\mathrm{DIM} \times \mathrm{FI} \times \mathrm{EF} \times \mathrm{ED}) / \mathrm{RFD} \times \mathrm{BW} \times \mathrm{AT})$

$\mathrm{THQ}=\sum \mathrm{HQ}$

(Eq. 1)

Where DIM is daily intake of heavy metals, FI is the fraction ingested from the contaminated source representing the fraction of consumed foodstuffs which enter the blood (equal to 0.4 ),

$E F$ is the exposure frequency (day) that was considered 365 days. $E D$ is the exposure duration (year) or the number of potentially exposed years, which was considered 6 and 37 years for children and adults, respectively. $B W$ is the body weight $(\mathrm{kg})$, which was considered 67.2 and $76.8 \mathrm{~kg}$ for adult male and female, respectively.

$A T$ is the average time for non-carcinogenic diseases (365 day $\left.{ }^{-1} \times \mathrm{ED}\right)$. $R F D$ is the oral reference dose that was considered $0.003,0.001$, and 0.0003 for $\mathrm{Pb}, \mathrm{Cd}$, and $\mathrm{As}$, respectively. HQ and THQ are hazard quotient and total hazard quotient, respectively (Eq. 1).

While the HQ is less than one, there is no adverse health effect as a result of exposure.

Results

Regardless of gender, the maximum and minimum $\mathrm{Pb}$ daily intake (DIM) was observed by considering the daily consumption of lettuce and basil (58 g/d) (16), with the amount of 0.00219 and $0.00027 \mathrm{mg} \mathrm{Pb} / \mathrm{kg} / \mathrm{d}$. It should be noted that the $\mathrm{Pb}$ daily intake in female was higher than that in male. The highest daily intake of $\mathrm{Cd}$ and As was due to the consumption of the same amount of lettuce as mentioned for $\mathrm{Pb}$. The lowest $\mathrm{Cd}$ daily intake was due to the consumption of $58 \mathrm{~g}$ fenugreek with $0.00008 \mathrm{mg}$ $\mathrm{Cd} / \mathrm{kg} / \mathrm{d}$. The minimum daily intake of As was due to the consumption of coriander with $0.00009 \mathrm{mg} \mathrm{As} / \mathrm{kg} / \mathrm{d}$ (Table 1). The Cd and As daily intake in female was higher than that in male.

The highest and lowest $\mathrm{Pb} \mathrm{HQ}$ was due to the daily consumption of $58 \mathrm{~g}$ lettuce and basil, respectively (12) 
Table 1. Mean daily intake of heavy metals via consumption of vegetables distributed in the fruits and vegetables central market of Arak in 2017

\begin{tabular}{|c|c|c|c|c|c|c|c|c|c|c|c|}
\hline \multirow{2}{*}{$\begin{array}{l}\text { Heavy } \\
\text { Metal }\end{array}$} & \multirow{2}{*}{ Gender } & \multicolumn{9}{|c|}{ Heavy metals intake $(\mathrm{mg} / \mathrm{kg} / \mathrm{d})$} & \multirow{2}{*}{$\begin{array}{l}\text { Total } \\
\text { intake }\end{array}$} \\
\hline & & Cabbage & Lettuce & Coriander & Basil & Cress & Fenugreek & Chard & Mint & Parsley & \\
\hline \multirow{2}{*}{$\mathrm{Pb}$} & Female & 0.00144 & 0.00219 & 0.00058 & 0.00027 & 0.00172 & 0.00104 & 0.00040 & 0.00043 & 0.00066 & 0.00873 \\
\hline & Male & 0.00126 & 0.00192 & 0.00050 & 0.00023 & 0.00150 & 0.00091 & 0.00035 & 0.00037 & 0.00057 & 0.00761 \\
\hline \multirow{2}{*}{$\mathrm{Cd}$} & Female & 0.00024 & 0.00034 & 0.00023 & 0.00016 & 0.00016 & 0.00010 & 0.00030 & 0.00019 & 0.00013 & 0.00185 \\
\hline & Male & 0.00021 & 0.00029 & 0.00020 & 0.00016 & 0.00014 & 0.00008 & 0.00026 & 0.00016 & 0.00011 & 0.00159 \\
\hline \multirow{2}{*}{ As } & Female & 0.00027 & 0.00030 & 0.00009 & 0.00016 & 0.00019 & 0.00026 & 0.00023 & 0.00022 & 0.00019 & 0.00191 \\
\hline & Male & 0.00023 & 0.00026 & 0.00007 & 0.00014 & 0.00016 & 0.00022 & 0.00020 & 0.00019 & 0.00016 & 0.00163 \\
\hline
\end{tabular}

with 0.73 and $0.09 \mathrm{mg} \mathrm{Pb} / \mathrm{kg} / \mathrm{d}$, respectively (Table 2). The highest As HQ was observed via the daily consumption of $58 \mathrm{~g}$ lettuce, while the lowest one was due to the consumption of the same amount of coriander (Table 2). However, the HQ of As for female was higher than that for male. As shown in Figure 2, the highest and lowest ratio of THQ was estimated to body intake of AS and Cd.

\section{Discussion}

According to the results of this study, the $\mathrm{Pb}$ daily intake by the consumption of cress, coriander, lettuce, and cabbage was significantly lower than the safe level recommended by the World Health Organization (WHO) (0.003 mg $\mathrm{Pb} / \mathrm{kg} / \mathrm{d}$ ) (28). However, the quality of these vegetables should be evaluated periodically. It is worth mentioning that $\mathrm{Pb}$ daily intake via the consumption of the studied vegetables in female was higher than that in male. It can be due to the lower body weight of female compared to male. Salehipour Baversad et al investigated the potential hazard of heavy metals on human health due to the consumption of some agricultural products of Isfahan province and reported that the $\mathrm{Pb}$ daily intake through the consumption of agricultural products was lower than the standard level recommended by the WHO (29). Tabande and Taheri also reported the high concentration of heavy metals in leafy vegetables grown in Zanjan province. They mentioned that industrial activities have important effects on heavy metals entrance into the food chain (16). On the other hand, Rehman et al investigated the transfer of heavy metals from soils to vegetables and associated human health risks at selected sites in Pakistan and concluded that there was no significant health risk for the local consumers through consumption of these food crops (30).

Huang et al investigated the heavy metals concentration in vegetables and the health risk to population in Zhejiang, China and concluded that there was no heavy metals contamination in their studied vegetables. However, considerable attentions should be paid to the potential contamination of heavy metals, especially $\mathrm{Cd}$, in vegetables (31). Therefore, further studies are required to investigate the concentration of heavy metals in food chain in different regions periodically.

The $\mathrm{Pb} \mathrm{HQ}$ due to the consumption of the studied vegetables was below one $(\mathrm{HQ}<1)$, indicating that there was no serious health risk related to $\mathrm{Pb}$ intake through the consumption of these vegetables. Although, this is not

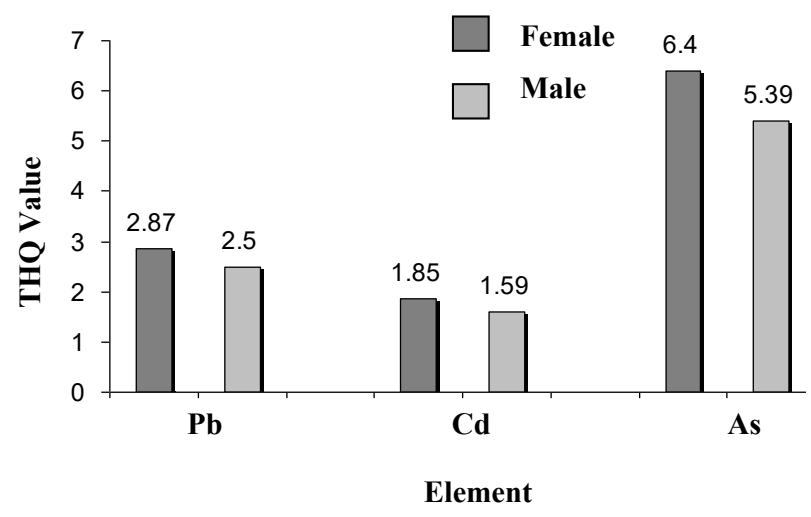

Figure 2. THQ value according to gender.

Table 2. The $\mathrm{HQ}$ of heavy metals in vegetables distributed in the fruits and vegetables central market of Arak in 2017

\begin{tabular}{|c|c|c|c|c|c|c|c|c|c|c|}
\hline \multirow{2}{*}{ Heavy Metal } & \multirow{2}{*}{ Gender } & \multicolumn{9}{|c|}{ HQ } \\
\hline & & Cabbage & Lettuce & Coriander & Basil & Cress & Fenugreek & Chard & Mint & Parsley \\
\hline \multirow{2}{*}{$\mathrm{Pb}$} & Female & 0.48 & 0.73 & 0.19 & 0.09 & 0.57 & 0.34 & 0.13 & 0.14 & 0.20 \\
\hline & Male & 0.42 & 0.63 & 0.16 & 0.07 & 0.50 & 0.30 & 0.11 & 0.12 & 0.19 \\
\hline \multirow{2}{*}{$\mathrm{Cd}$} & Female & 0.24 & 0.34 & 0.23 & 0.16 & 0.16 & 0.10 & 0.30 & 0.19 & 0.13 \\
\hline & Male & 0.21 & 0.29 & 0.20 & 0.14 & 0.14 & 0.08 & 0.26 & 0.16 & 0.11 \\
\hline \multirow{2}{*}{ As } & Female & 0.90 & 1.10 & 0.30 & 0.53 & 0.63 & 0.86 & 0.76 & 0.73 & 0.63 \\
\hline & Male & 0.76 & 0.86 & 0.23 & 0.46 & 0.53 & 0.73 & 0.66 & 0.63 & 0.53 \\
\hline
\end{tabular}


the only entrance way of heavy metals into the human body that should be considered. According to the results of Figure 1, the THQ of each heavy metals due to the consumption of all studied vegetables were higher than the safe level (THQ>1), which is harmful to human health and should be considered. The highest $\mathrm{Pb}$ HQ was related to the consumption of lettuce, which is consistent with the results of the study of Mohajer et al (32).

As shown in Table 1, the Cd daily intake was below the standard level $(0.001 \mathrm{mg} / \mathrm{kg} / \mathrm{d})(32)$, that is a positive point in environmental studies and implies the safety of vegetables distributed in the fruits and vegetables central market of Arak. According to this table, the HQ of each vegetables is in the standard range $(\mathrm{HQ}=1)$, but total consumption of the studied vegetables increased the HQ over the standard level with a mean of 1.85 and 1.59 for female and male, respectively (Figure 1).

Kheirabadi el al investigated the risk of heavy metals in soil and crops grown in Hamedan province and concluded that children and adults in the study area were exposed to the non-carcinogenic diseases due to the entrance of heavy metals into the food chain (25). Loutfy et al reported that oral intake is the main way of heavy metals entrance into the body compared with other ways, such as inhalation and dermal contact. Low weight and low IQ in newborn children are the adverse effects of heavy metals intake (33). According to Table 1, the daily intake of arsenic caused by the consumption of each of the studied vegetables is below the standard level, which is $0.015 \mathrm{mg} \mathrm{As} / \mathrm{kg} / \mathrm{d}$ (34). As a positive point, the As daily intake though the consumption of all studied vegetables was also below the standard level (29). However, Table 2 shows that the HQ of the As daily intake through the consumption of lettuce distributed in the fruits and vegetables central market of Arak was higher than the standard level $(\mathrm{HQ}=1)$ in both gender groups. It may be due to the soil contamination by As, where vegetables were cultivated.

Among the studied heavy metals, the highest THQ belonged to As through the consumption of all studied vegetables distributed in the fruits and vegetables central market of Arak. The highest As HQ confirms this matter clearly. The study of Salehipour Baversad et al also showed that the THQ of AS was higher than that of $\mathrm{Pb}$ (29). Chary et al also showed that the THQ of $\mathrm{Cd}, \mathrm{Pb}$, and $\mathrm{Zn}$ through the consumption of contaminated vegetables is very high. In addition, they reported that leafy vegetables absorb high levels of heavy metals (35). Khan et al also reported that the consumption of vegetables grown in the industrial zone of northern Pakistan have adverse effects on human health. In addition, they mentioned that $\mathrm{Pb}$ in adults and $\mathrm{Cd}, \mathrm{Cu}$, and $\mathrm{Pb}$ in children cause harmful effects on human health (36). Amin et al evaluated the concentration of $\mathrm{As}, \mathrm{Cd}$ and $\mathrm{Pb}$ in potatoes in southeast of Isfahan and concluded that the $\mathrm{Pb}$ and $\mathrm{Cd}$ concentration is higher than the standard level but the As concentration is below the standard level (37).

\section{Conclusion}

The results of this study showed that the highest daily intake of $\mathrm{Pb}, \mathrm{Cd}$, and As was due to the consumption of lettuce distributed in the fruits and vegetables central market of Arak in 2017, which was higher in female compared to male. In addition, the highest and lowest daily intake of the studied vegetables heavy metals belonged to $\mathrm{Pb}$ and $\mathrm{Cd}$. As had the highest risk of noncarcinogenic diseases. However, climatic conditions, soil contamination and type of the metal can affect the heavy metal concentration. Thereby, further regional studies at different times are required to investigate these factors.

\section{Acknowledgments}

The authors would like to thank the Islamic Azad University of Arak for supporting this research.

\section{Ethical issues}

The authors hereby certify that this manuscript is the original work of the authors, all data collected during the study are as stated in this manuscript, and no data from this study has been or will be published elsewhere separately.

\section{Competing interests}

The authors declare that they have no competing interests.

\section{Authors' contributions}

All authors were equally involved in the collection, analysis, and interpretation of the data. All authors critically reviewed, refined, and approved the manuscript.

\section{References}

1. Aysha MI, Zakir HM, Haque R, Quadir QF, Choudhury TR, Quraishi SB, et al. Health risk assessment for population via consumption of vegetables grown in soils artificially contaminated with arsenic. Archives of Current Research International 2017; 10(3): 1-12. doi: 10.9734/ ACRI/2017/37612.

2. Kaur C, Kapoor HC. Antioxidants in fruits and vegetables the millennium's health. Int J Food Sci Technol 2001; 36(7): 703-25. doi: 10.1111/j.1365-2621.2001.00513.x.

3. Lima GP, Vianello F, Correa CR, da Silva Campos RA, Borguini MG. Polyphenols in fruits and vegetables and its effect on human health. Food and Nutrition Sciences 2014; 5(11): 1065-82. doi: 10.4236/fns.2014.511117.

4. Li X, Li Z, Lin CJ, Bi X, Liu J, Feng X, et al. Health risks of heavy metal exposure through vegetable consumption near a large-scale $\mathrm{Pb} / \mathrm{Zn}$ smelter in central China. Ecotoxicol Environ Saf 2018; 161: 99-110. doi: 10.1016/j. ecoenv.2018.05.080.

5. Nazemi S, Asgari AR, Raei M. Survey the amount of heavy metals in cultural vegetables in suburbs of Shahroud. Iranian Journal of Health and Environment 2010; 3(2): 195202. [In Persian].

6. Meng J, Tao M, Wang L, Liu X, Xu J. Changes in heavy metal bioavailability and speciation from a $\mathrm{Pb}-\mathrm{Zn}$ mining soil amended with biochars from co-pyrolysis of rice straw 
and swine manure. Sci Total Environ 2018; 633: 300-7. doi: 10.1016/j.scitotenv.2018.03.199.

7. Chen $\mathrm{H}$, Yang $\mathrm{X}$, Wang $\mathrm{P}$, Wang Z, Li M, Zhao FJ. Dietary cadmium intake from rice and vegetables and potential health risk: a case study in Xiangtan, southern China. Sci Total Environ 2018; 639: 271-7. doi: 10.1016/j. scitotenv.2018.05.050.

8. Nawab J, Ghani J, Khan S, Xiaoping W. Minimizing the risk to human health due to the ingestion of arsenic and toxic metals in vegetables by the application of biochar, farmyard manure and peat moss. J Environ Manage 2018; 214: 17283. doi: 10.1016/j.jenvman.2018.02.093.

9. da Silva WR, da Silva FBV, Araujo PRM, do Nascimento CWA. Assessing human health risks and strategies for phytoremediation in soils contaminated with $\mathrm{As}, \mathrm{Cd}, \mathrm{Pb}$, and $\mathrm{Zn}$ by slag disposal. Ecotoxicol Environ Saf 2017; 144: 522-30. doi: 10.1016/j.ecoenv.2017.06.068.

10. Liu B, Ai S, Naeem S, Ding J, Ji W, Zhang Y. Metal bioaccessibility in a wastewater irrigated soil-wheat system and associated human health risks: implications for regional thresholds. Ecol Indic 2018; 94 (Pt 1): 305-11. doi: 10.1016/j.ecolind.2018.06.054.

11. Wu W, Wu P, Yang F, Sun DL, Zhang DX, Zhou YK. Assessment of heavy metal pollution and human health risks in urban soils around an electronics manufacturing facility. Sci Total Environ 2018; 630: 53-61. doi: 10.1016/j. scitotenv.2018.02.183.

12. Doabi SA, Karami M, Afyuni M, Yeganeh M. Pollution and health risk assessment of heavy metals in agricultural soil, atmospheric dust and major food crops in Kermanshah province, Iran. Ecotoxicol Environ Saf 2018; 163: 153-64. doi: 10.1016/j.ecoenv.2018.07.057.

13. Gope M, Masto RE, George J, Hoque RR, Balachandran $\mathrm{S}$. Bioavailability and health risk of some potentially toxic elements $(\mathrm{Cd}, \mathrm{Cu}, \mathrm{Pb}$ and $\mathrm{Zn})$ in street dust of Asansol, India. Ecotoxicol Environ Saf 2017; 138: 231-41. doi: 10.1016/j.ecoenv.2017.01.008.

14. Pareja-Carrera J, Mateo R, Rodriguez-Estival J. Lead ( $\mathrm{Pb})$ in sheep exposed to mining pollution: implications for animal and human health. Ecotoxicol Environ Saf 2014; 108: 210-6. doi: 10.1016/j.ecoenv.2014.07.014.

15. Tan SY, Praveena SM, Abidin EZ, Cheema MS. A review of heavy metals in indoor dust and its human health-risk implications. Rev Environ Health 2016; 31(4): 447-56. doi: 10.1515/reveh-2016-0026.

16. Tabande L, Taheri M. Evaluation of exposure to heavy metals $\mathrm{Cu}, \mathrm{Zn}, \mathrm{Cd}$ and $\mathrm{Pb}$ in vegetables grown in the olericultures of Zanjan province's fields. Iranian Journal of Health and Environment 2016; 9(1): 41-56. [In Persian].

17. Bai J, Cui B, Chen B, Zhang K, Deng W, Gao H, et al. Spatial distribution and ecological risk assessment of heavy metals in surface sediments from a typical plateau lake wetland, China. Ecol Modell 2011; 222(2): 301-6. doi: 10.1016/j. ecolmodel.2009.12.002.

18. Liu X, Song Q, Tang Y, Li W, Xu J, Wu J, et al. Human health risk assessment of heavy metals in soil-vegetable system: a multi-medium analysis. Sci Total Environ 2013; 463-464: 530-40. doi: 10.1016/j.scitotenv.2013.06.064.

19. Yi Y, Yang Z, Zhang S. Ecological risk assessment of heavy metals in sediment and human health risk assessment of heavy metals in fishes in the middle and lower reaches of the Yangtze River basin. Environ Pollut 2011; 159(10): 2575-85. doi: 10.1016/j.envpol.2011.06.011.

20. Malakootian M, Mahdizadeh $H$, Nasiri A, Mirzaienia F, Hajhoseini M, Amirmahani N. Investigation of the efficiency of microbial desalination cell in removal of arsenic from aqueous solutions. Desalination 2018; 438: 19-23. doi: 10.1016/j.desal.2018.03.025.

21. Qishlaqi A, Moore F, Forghani G. Impact of untreated wastewater irrigation on soils and crops in Shiraz suburban area, SW Iran. Environ Monit Assess 2008; 141(1-3): 25773. doi: 10.1007/s10661-007-9893-X.

22. Alidadi Khaliliha M, Dordipour E, Barani Motlagh M. Interactive effect of iron and lead on growth and their uptake in Cress (Lepidium sativum L.). Electronic Journal of Soil Management and Sustainable Production 2016; 5(4):41-59. [In Persian].

23. Li N, Kang Y, Pan W, Zeng L, Zhang Q, Luo J. Concentration and transportation of heavy metals in vegetables and risk assessment of human exposure to bioaccessible heavy metals in soil near a waste-incinerator site, South China. Sci Total Environ 2015; 521-522: 144-51. doi: 10.1016/j. scitotenv.2015.03.081.

24. Zhao H, Xia B, Fan C, Zhao P, Shen S. Human health risk from soil heavy metal contamination under different land uses near Dabaoshan Mine, Southern China. Sci Total Environ 2012; 417-418: 45-54. doi: 10.1016/j. scitotenv.2011.12.047.

25. Kheirabadi H, Afyuni M, Ayoubi S, Soffianian A. Risk assessment of heavy metals in soils and major food crops in the province of Hamadan. Journal of Water and Soil Science 2016; 19(74): 27-38. doi: 10.18869/acadpub.jstnar.19.74.3. [In Persian].

26. Aghili F, Khoshgoftarmanesh AH, Afyuni M, Schulin R. Health risks of heavy metals through consumption of greenhouse vegetables grown in central Iran. Hum Ecol Risk Assess 2009; 15(5): 999-1015. doi: 10.1080/10807030903153337.

27. Yeganeh $M$, Afyuni $M$, Khoshgoftarmanesh AH, Khodakarami L, Amini M, Soffyanian AR, et al. Mapping of human health risks arising from soil nickel and mercury contamination. J Hazard Mater 2013; 244-245: 225-39. doi: 10.1016/j.jhazmat.2012.11.040.

28. Khoshgoftarmanesh AH, Aghili F, Sanaeiostovar A. Daily intake of heavy metals and nitrate through greenhouse cucumber and bell pepper consumption and potential health risks for human. Int J Food Sci Nutr 2009; 60 Suppl 1: 199-208. doi: 10.1080/09637480902755087.

29. Salehipour Baversad M, Ghorbani H, Afyuni M, Kheirabadi $\mathrm{H}$. The potential risk assessment of heavy metals on human health in some agricultural products in Isfahan province. Journal of Water and Soil Science 2014; 18(67): 71-81. [In Persian].

30. Rehman ZU, Khan S, Shah MT, Brusseau ML, Khan SA, Mainhagu J. Transfer of heavy metals from soils to vegetables and associated human health risks at selected sites in Pakistan. Pedosphere 2018; 28(4): 666-79. doi: 10.1016/S1002-0160(17)60440-5.

31. Huang Z, Pan XD, Wu PG, Han JL, Chen Q. Heavy metals in vegetables and the health risk to population in Zhejiang, 
China. Food Control 2014; 36(1): 248-52. doi: 10.1016/j. foodcont.2013.08.036.

32. Mohajer R, Salehi MH, Mohammadi J. Lead and cadmium concentration in agricultural crops (lettuce, cabbage, beetroot, and onion) of Isfahan Province, Iran. Iranian Journal of Health and Environment 2014; 7(1): 1-10. [In Persian]

33. Loutfy N, Fuerhacker M, Tundo P, Raccanelli S, El Dien AG, Ahmed MT. Dietary intake of dioxins and dioxin-like PCBs, due to the consumption of dairy products, fish/seafood and meat from Ismailia city, Egypt. Sci Total Environ 2006; 370(1): 1-8. doi: 10.1016/j.scitotenv.2006.05.012.

34. Kolahkaj M, Battaleblooie S, Amanipoor H, Modabberi S. Study of arsenic accumulation in rice and its exposure dose in residents of Meydavood area, Khoozestan province. Iranian Journal of Health and Environment 2017; 9(4): 537-
44. [In Persian].

35. Chary NS, Kamala CT, Raj DS. Assessing risk of heavy metals from consuming food grown on sewage irrigated soils and food chain transfer. Ecotoxicol Environ Saf 2008; 69(3): 513-24. doi: 10.1016/j.ecoenv.2007.04.013.

36. Khan S, Rehman S, Khan AZ, Khan MA, Shah MT. Soil and vegetables enrichment with heavy metals from geological sources in Gilgit, northern Pakistan. Ecotoxicol Environ Saf 2010; 73(7): 1820-7. doi: 10.1016/j.ecoenv.2010.08.016.

37. Amin MM, Saffari-Khoozani H, Vahid-Dastjerdi M. The concentration of three heavy metals, arsenic, cadmium, and lead, in potatoes in farms the south-east area of Isfahan province, Iran, in 2016. Journal of Health System Research 2018; 13(4): 478-84. doi: 10.22122/jhsr.v13i4.3096. [In Persian]. 